\title{
CHANGES OF PRODUCTIVITY IN THE TOURISM SECTOR OF THE EU BEFORE THE PANDEMIC- IMPLICATIONS FOR POLICIES AFTER COVID-19
}

\author{
Roman LACKO, PhD \\ University of Economics in Bratislava, Slovakia \\ roman.lacko@euba.sk \\ Zuzana HAJDUOVÁ, PhD \\ University of Economics in Bratislava, Slovakia \\ zuzana.hajduova@euba.sk \\ František SEBESTYÉN, Ph.D. student \\ University of Economics in Bratislava, Slovakia \\ frantisek.sebestyén@euba.sk \\ Pavol ANDREJOVSKÝ, PhD \\ University of Economics in Bratislava, Slovakia \\ pavol.andrejovsky@euba.sk
}

\begin{abstract}
The constraints caused by the fight against COVID-19 have hit the tourism sector the hardest of all. The tourism industry's backbone services, such as accommodation and catering, but also the services partially related to transport, arts and entertainment have declined by tens of percent year-on-year. The business environment plays an important role in achieving economic growth. Tourism is also a key sector contributing to economic growth. We can conclude that tourism is one of the worst affected areas. Under various restrictive measures introduced by governments and national authorities, the number of foreign and domestic tourists has fallen. Using descriptive and sampling statistical methods, we will assess the significance of pandemic-related changes at EU country level. Based on these findings and an evaluation of measures against the spread of the coronavirus, we apply regression modelling to identify the impact of these decisions on the performance of tourism indicators. We decided to quantify the efficiency of investments and subsidies to rescue and revitalize tourism entities. Based on the results, we reached conclusions that contribute to the prosperity of tourism in the European countries. EU countries should invest primarily in infrastructure. Country leaders should promote the idea of sustainable 'green' tourism on the basis of improving the conditions for doing business in this area.
\end{abstract}

Keywords: productivity, tourism, Malmquist index, the European Union. 


\section{Introduction}

The tourism sector is one of the most affected by the COVID-19 pandemic. Many authors examine the negative effects of the pandemic on tourism and try to find possible connections that would help to restore and minimize extreme losses (Kinnuen et al., 2021; Żak \& Garncarz, 2020). As such a pandemic has not occurred in recent history, it is very difficult to predict future developments. Therefore, we should learn from other crises and adopt specific acts that have helped to resolve crises in the past. One of the possibilities to evaluate the development in the postcrisis years is also the measurement of productivity, which can also be applied to the field of tourism. Such an approach has proved to be an effective tool for policy implementation in the past. The authors (Sun et al., 2015) have been researching the causes of changes in productivity for many years. These can be caused, for example, by technological changes (Oláh et al., 2019 Koraus et al., 2017a), economic changes, innovation (Piątkowski, 2020; Korshenkov, Ignatyev, 2020; Chenghu et al., 2021;), but also by managerial resp. political decisions. EU subsidy programmes play an essential role in the process (Halasi et al., 2019; Androniceanu, 2020; Marišová et al., 2021). According to (Barros and Alves, 2004; Corne and Peypoch, 2020; Peypoch and Solonandrasana, 2008; Mariš, 2019), measuring productivity using efficiency measurement methods is an effective tool for evaluating various impacts. Such measurements can be performed on many types of entities, such as hotels, countries, etc. (Cho and Wang, 2018; Mavi and Mavi, 2019; Marčeková et al., 2021). These entities cooperate in many in different areas, for exampole in clusters (Havierniková et al., 2017; Mura and Kajzar, 2018; Prokopenko and Omelyanenko, 2020). Many studies suggest that the increase in efficiency and productivity was evident after the crisis in 2009 (Bampatsou et al., 2020; Rudminas \& Baležentis, 2020). However, there are still significant differences between the countries (Soysal-Kurt, 2017; Dobrovic et al., 2018; Androniceanu and Marton, 2021). Especially nowadays, however, the importance of research in the field of efficiency and productivity of tourism is growing worldwide. Countries are looking for competitive advantages that they can use to apply after the pandemic (Prokopenko et al. 2020; Radjenovic et al., 2020; Skare, Kukurin, 2020). About the development of ecological and social entrepreneurship write Prokopenko et al., 2020; Bilan et al., 2017; Csikósová et al., 2020. Options to increase tourism productivity might be state intervention or private innovation, as well as combination of both (Zhang et al., 2021; Mura 2020; Koraus et al., 2017b). The EU Green deal 
initiated the approval of the Envirostrategy 2030, which aims at decreasing recycling and landfilling rate by 2030 (Valenčiková and Marišová, 2021). Based on this, we decided in this study, which was the main reason for the enormous productivity growth in EU countries in the years before the COVID-19 pandemic (Duro et al., 2021; Zopiatis et al., 2021). This paper focuses to assess the causes of growth in the tourism sector in the period after the financial crisis in 2009 and before the pandemic crisis that began in 2019. Based on this, it will be possible to propose the direction sources to renovate the tourism sector.

\section{Materials and methods}

In this section, we provide a brief description of the methods and materials used in this study.

\subsection{Productivity measurement}

There are various measures of productivity in the modern economy and contemmporary business (Makieła, Wojciechowski \& Wach, 2021). The Malmquist Productivity Index (MPI) measures changes in productivity along with changes in time and can be broken down into changes in efficiency and changes in technology using a non-parametric DEA approach. The MPI can be expressed by the distance function (E) as equation

(1) and equation (2) by observations at time $t$ and $t+1$.

$$
\begin{gathered}
M P I_{I}^{t}=\frac{E_{I}^{t}\left(x^{t+1}, y^{t+1}\right)}{E_{I}^{t}\left(x^{t}, y^{t}\right)} \\
M P I_{I}^{t+1}=\frac{E_{I}^{t+1}\left(x^{t+1}, y^{t+1}\right)}{E_{I}^{t+1}\left(x^{t}, y^{t}\right)}
\end{gathered}
$$

where $\mathrm{x}$ is the input vector, $\mathrm{y}$ is the output vector and „I “denote the model orientation (Input). The geometric mean of MPI from equations (1) and (2) can be calculated as shown in equation (3).

$$
M P I_{I}^{G}=\left(M P I_{I}^{t} \cdot M P I_{I}^{t+1}\right)^{1 / 2}=\left[\left(\frac{E_{I}^{t}\left(x^{t+1}, y^{t+1}\right)}{E_{I}^{t}\left(x^{t}, y^{t}\right)}\right) \cdot\left(\frac{E_{I}^{t+1}\left(x^{t+1}, y^{t+1}\right)}{E_{I}^{t+1}\left(x^{t}, y^{t}\right)}\right)\right]^{1 / 2}
$$

The geometric mean can be divided into so-called technological change (TECHCH) - change in technological efficiency (TE) and change in efficiency (EFFCH) - change in managerial efficiency (ME); see equation (4). 


$$
\begin{aligned}
& M P I_{I}^{G}=\left(E_{F F C H} \cdot T E C H C H_{I}^{G}\right)^{1 / 2}= \\
& =\left(\frac{E_{I}^{t+1}\left(x^{t+1}, y^{t+1}\right)}{E_{I}^{t}\left(x^{t}, y^{t}\right)}\right) \cdot\left[\left(\frac{E_{I}^{t}\left(x^{t}, y^{t}\right)}{E_{I}^{t+1}\left(x^{t}, y^{t}\right)}\right) \cdot\left(\frac{E_{I}^{t}\left(x^{t+1}, y^{t+1}\right)}{E_{I}^{t+1}\left(x^{t+1}, y^{t+1}\right)}\right)\right]^{1 / 2}
\end{aligned}
$$

Technological change is caused by changes in technology (investments in new machines, buildings). The change of efficiency is caused by managerial decisions. If the value of the indicator is greater than 1, it means that there has been an increase in efficiency (productivity). If the value is less than 1, it means that there has been a decrease in efficiency (productivity) (Färe et al., 1994).

\subsection{Research object}

The study is addressing the countries of the European Union (EU 27). The research was conducted during the inter-crisis period, between 2010 and 2018, the countries were analyzed using the Malmquist productivity index. The reason for choosing the research subject is the integrity of EU policies and directions, as well as the interconnectedness of the EU countries.

\subsection{Data}

Based on a literature review, we have identified several variables that are often used to measure efficiency and productivity in the tourism industry. The indicators we used in this study are listed in Table 1.

\begin{tabular}{|c|c|c|}
\hline & Variable & Units \\
\hline \multirow{4}{*}{ Inputs } & Number of employees in HORECA sector & $\begin{array}{l}\text { Thousand } \\
\text { persons }\end{array}$ \\
\hline & $\begin{array}{c}\text { Number of employees in travel agencies, reservation systems, } \\
\text { and other }\end{array}$ & $\begin{array}{l}\text { Thousand } \\
\text { persons }\end{array}$ \\
\hline & Number of beds in accommodation facilities & Number \\
\hline & Protected natural areas - Natura 2000 & $\mathrm{~km}^{2}$ \\
\hline \multirow{2}{*}{ Outputs } & The net occupancy rate of beds & $\%$ \\
\hline & Gross domestic product from tourism in current prices & mil. $€$ \\
\hline
\end{tabular}

Table 1 Variables used in calculation of MPI in tourism

The first two input variables relate to the production factor of labour and capture the number of employees in accommodation establishments and travel agencies (Huang, 2018; Martín et al., 2017). The number of beds in accommodation facilities indicates the capital capacity in tourism, 
the term is widely used in the available scientific literature (Niavis and Tsiotas, 2019, 2019). The area of protected areas according to Natura 2000 methodology is also an input that concerns production factors, specifically land area. It is assumed that a country with a higher proportion of protected areas should also attract more tourists (Benito et al., 2014). As outputs of our MPI model, we chose Bed Occupancy (Corne, 2015; Qiu et al., 2017), which tells about how the country uses its capacities. Finally, we chose GDP generated by tourism as an output related to the economic impacts of tourism (Chaabouni, 2019; Ilić and Petrevska, 2018; Maris et al., 2019). Data in this study were obtained from databases of Eurostat and the World Bank. (Eurostat, 2021; The World Bank, 2021)

\section{Results}

Graph 1 shows the geometric mean of MPI values, changes in managerial efficiency and technological change for the tourism sector.

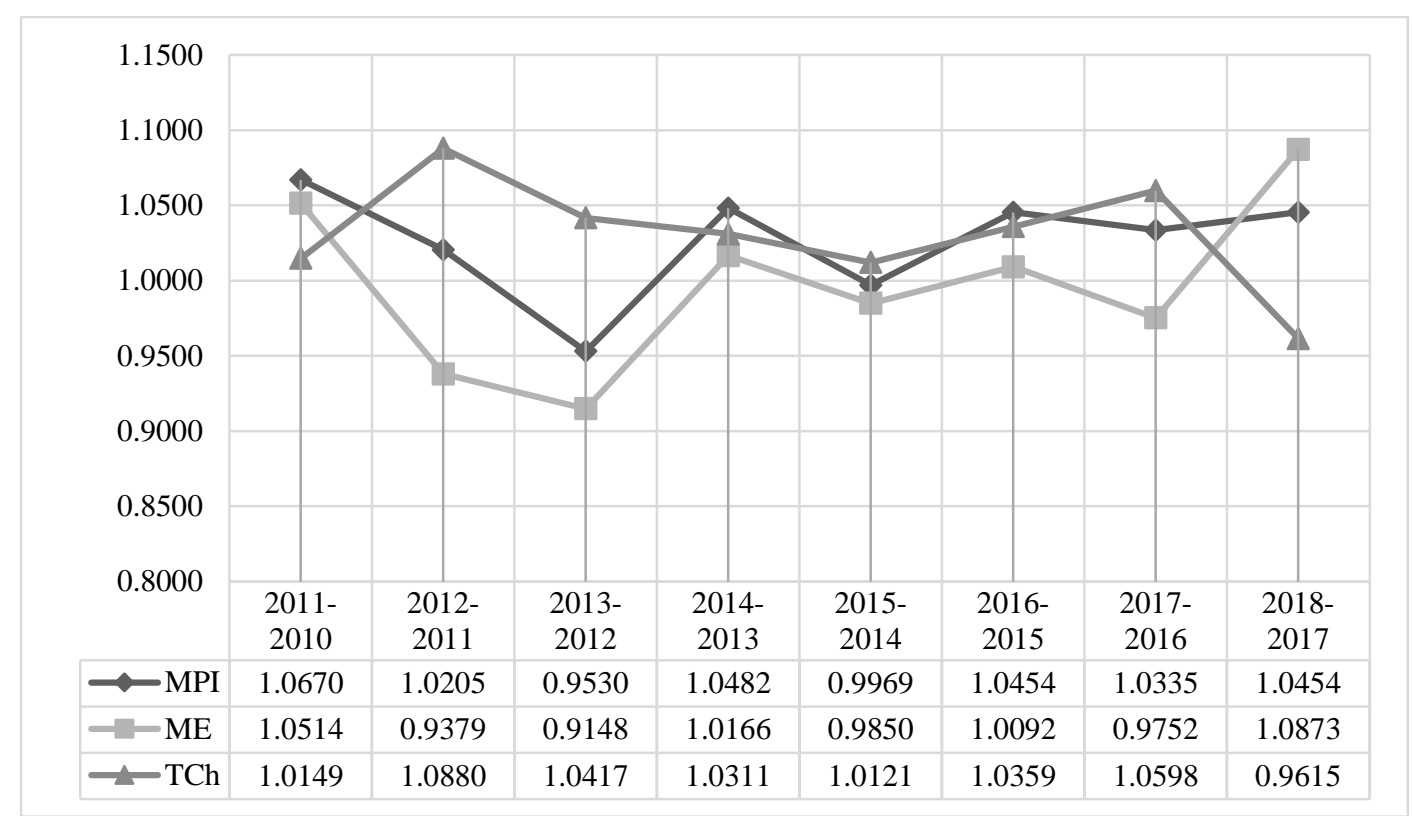

Graph 1 Development of changes in productivity in the case of tourism efficiency - geometric average

Source: own calculation.

The productivity of countries in terms of tourism efficiency varied in the EU countries during the period under review. The value of MPI increased significantly when comparing the obtained data from 2011 and 2010, specifically by 6.7\%. Productivity decreased slightly during the period 
2013/2012 and the period 2015/2014. The trend in the change of managerial and technological efficiency was significantly fluctuating. In the periods 2011/2010 and 2018/2017, the positive impact of managerial changes prevailed over technological changes, but in all the remaining periods it was the opposite. Table 2 shows the results of measuring productivity changes for each EU country.

Table 2 Results of the Malmquist productivity index analysis for tourism efficiency

\begin{tabular}{|c|c|c|c|c|c|c|c|c|c|}
\hline \multirow{2}{*}{ Country } & \multicolumn{3}{|c|}{$2011-2010$} & \multicolumn{3}{|c|}{$2015-2014$} & \multicolumn{3}{|c|}{ 2018-2017 } \\
\hline & MPI & $\mathrm{ME}$ & $\mathrm{TE}$ & MPI & $\mathrm{ME}$ & $\mathrm{TE}$ & MPI & $\mathrm{ME}$ & $\mathrm{TE}$ \\
\hline Belgium & 1.043 & 1.023 & 1.019 & 0.999 & 1.058 & 0.944 & 1.005 & 0.968 & 1.038 \\
\hline Bulgary & 1.173 & 1.029 & 1.140 & 1.246 & 1.131 & 1.102 & 1.346 & 1.535 & 0.877 \\
\hline Cyprus & 1.369 & 1.397 & 0.980 & 1.072 & 1.099 & 0.976 & 1.315 & 1.622 & 0.811 \\
\hline Czechia & 1.100 & 1.112 & 0.989 & 1.081 & 1.215 & 0.890 & 1.026 & 1.117 & 0.919 \\
\hline Denmark & 0.982 & 1.000 & 0.982 & 0.967 & 1.000 & 0.967 & 1.091 & 1.000 & 1.091 \\
\hline Estonia & 0.977 & 0.989 & 0.988 & 1.036 & 1.072 & 0.966 & 0.952 & 1.023 & 0.930 \\
\hline Finland & 1.125 & 1.079 & 1.043 & 0.892 & 0.789 & 1.129 & 1.016 & 1.071 & 0.949 \\
\hline France & 1.043 & 1.000 & 1.043 & 1.110 & 1.000 & 1.110 & 1.009 & 1.011 & 0.999 \\
\hline Greece & 1.034 & 0.961 & 1.076 & 1.030 & 1.029 & 1.002 & 1.446 & 1.534 & 0.943 \\
\hline Netherlands & 1.023 & 1.000 & 1.023 & 1.026 & 0.969 & 1.058 & 1.029 & 0.986 & 1.044 \\
\hline Croatia & 1.671 & 1.347 & 1.241 & 1.095 & 0.967 & 1.133 & 0.892 & 0.949 & 0.939 \\
\hline Ireland & 1.012 & 1.016 & 0.996 & 1.496 & 1.475 & 1.014 & 1.248 & 1.199 & 1.041 \\
\hline Lithuania & 0.907 & 0.927 & 0.979 & 1.055 & 1.232 & 0.857 & 0.965 & 0.966 & 0.999 \\
\hline Latvia & 1.010 & 1.033 & 0.979 & 1.150 & 1.263 & 0.910 & 0.987 & 0.988 & 0.999 \\
\hline Luxembourg & 0.874 & 1.000 & 0.874 & 0.888 & 1.000 & 0.888 & 0.892 & 1.000 & 0.892 \\
\hline Hungary & 0.988 & 0.984 & 1.004 & 1.235 & 1.174 & 1.051 & 1.382 & 1.446 & 0.956 \\
\hline Malta & 0.991 & 1.000 & 0.991 & 1.057 & 1.000 & 1.057 & 0.927 & 1.000 & 0.927 \\
\hline Germany & 1.050 & 1.035 & 1.015 & 1.025 & 1.066 & 0.962 & 1.037 & 1.025 & 1.012 \\
\hline Poland & 0.999 & 1.034 & 0.965 & 1.114 & 1.120 & 0.995 & 1.049 & 0.981 & 1.070 \\
\hline Portugal & 1.294 & 1.241 & 1.042 & 1.015 & 0.972 & 1.045 & 0.816 & 0.851 & 0.958 \\
\hline Austria & 1.122 & 1.140 & 0.984 & 1.059 & 1.197 & 0.885 & 1.059 & 1.154 & 0.917 \\
\hline Romania & 1.100 & 1.077 & 1.021 & 1.037 & 1.066 & 0.972 & 1.244 & 1.335 & 0.932 \\
\hline Slovakia & 1.003 & 0.989 & 1.014 & 1.062 & 1.068 & 0.995 & 0.915 & 0.914 & 1.001 \\
\hline Slovenia & 1.016 & 1.149 & 0.885 & 1.777 & 2.180 & 0.815 & 1.115 & 1.394 & 0.800 \\
\hline Spain & 1.031 & 0.954 & 1.081 & 0.908 & 0.813 & 1.117 & 0.885 & 0.912 & 0.970 \\
\hline Sweden & 1.126 & 1.012 & 1.113 & 1.097 & 1.000 & 1.097 & 0.977 & 1.000 & 0.977 \\
\hline Italy & 1.000 & 1.000 & 1.000 & 0.968 & 1.000 & 0.968 & 0.920 & 0.883 & 1.042 \\
\hline
\end{tabular}

Source: own calculation. 
Between 2011 and 2010, the highest increase in MPI values occurred in the case of Cyprus (36.9\%) and Croatia (67.1\%). Between 2015 and 2014, a high increase in MPI was recorded in Ireland (49.6\%) and Slovenia (77.7\%). Between 2018 and 2017, high growth was recorded for Bulgaria (34.6\%) and Greece (44.6\%). A slight increase has been detected in some of the EU countries. Slovakia recorded a slight increase in 2011/2010 (0.3\%) and 2015/2014 (6.2\%), followed by a decrease in MPI by 8.5\% between 2018 and 2017. The most signficant increase in productivity was detected in Hungary in the V4 group. Table 3 shows the comparison of changes in productivity between 2010 and 2018. The disadvantage is therefore that such a recalculation does not capture the development in the middle of the period considered.

Table 3 Comparison of changes in productivity between years 2010 and 2018

\begin{tabular}{cccc}
\hline \multirow{2}{*}{ Country } & \multicolumn{3}{c}{$2018-2010$} \\
\cline { 2 - 4 } & MPI & ME & TE \\
\hline Belgium & 1.298 & 0.901 & 1.440 \\
Bulgary & 1.600 & 1.408 & 1.137 \\
Cyprus & 1.586 & 1.397 & 1.135 \\
Czechia & 1.317 & 1.081 & 1.218 \\
Denmark & 1.221 & 1.000 & 1.221 \\
Estonia & 1.039 & 0.964 & 1.078 \\
Finland & 1.123 & 0.924 & 1.215 \\
France & 1.046 & 0.914 & 1.144 \\
Greece & 0.886 & 0.789 & 1.123 \\
Netherlands & 1.145 & 0.821 & 1.396 \\
Croatia & 0.792 & 0.665 & 1.191 \\
Ireland & 2.291 & 1.819 & 1.259 \\
Lithuania & 0.977 & 0.980 & 0.997 \\
Latvia & 1.374 & 1.319 & 1.042 \\
Luxembourg & 0.944 & 1.000 & 0.944 \\
Hungary & 1.513 & 1.260 & 1.201 \\
Malta & 1.349 & 1.000 & 1.349 \\
Germany & 1.293 & 1.075 & 1.202 \\
Poland & 1.205 & 1.018 & 1.184 \\
Portugal & 1.110 & 0.895 & 1.240 \\
Austria & 1.335 & 1.110 & 1.203 \\
Romania & 1.349 & 1.141 & 1.182 \\
Slovakia & 1.098 & 0.929 & 1.182 \\
Slovenia & 1.049 & 1.064 & 0.985 \\
Spain & 0.885 & 0.780 & 1.134 \\
Sweden & 1.291 & 1.012 & 1.275 \\
Italy & 1.022 & 0.761 & 1.343 \\
\hline & &
\end{tabular}

Source: own calculation. 
If we compare the years 2010 and 2018, the highest increase occurred in the case of Ireland, by $129.1 \%$. There was also a significant increase in Bulgaria by $60 \%$ and Cyprus by $58.6 \%$. A significant decrease was recorded in Croatia (20.8\%). The highest increase among V4 countries was recorded in Hungary (51.3\%), the Czech Republic (31.7\%), Poland (20.5\%) and Slovakia (9.8\%). In Slovakia, as the only V4 country, there has been a decline in managerial efficiency.

\section{Discussion and conclusions}

Based on the results of our study, several findings can be concluded. After 2010, there was significant decline in productivity until 2013. The reason was probably the consequences of the financial crisis and reduced demand for farmers due to lack of funds. It can be argued that tourism is a luxury asset that one does not necessarily need to survive, and perceived as a marginal activity in critical years. However, the crisis has different meaning for a group of people who lack finances and those who are afraid to be infected. Subsequently, there was a gradual revival of tourism after 2013. In EU countries, Technological change has been the main catalyst of recovery in the EU countries. However, this changed in 2018. In 2018, the increase in productivity was due to the greater impact of managerial changes. It can be explained by the fact that policies promoting tourism have outpaced policies to invest in accommodation and services. The following figure shows the regional differences in the growth/decline of productivity in tourism sector of the EU countries.

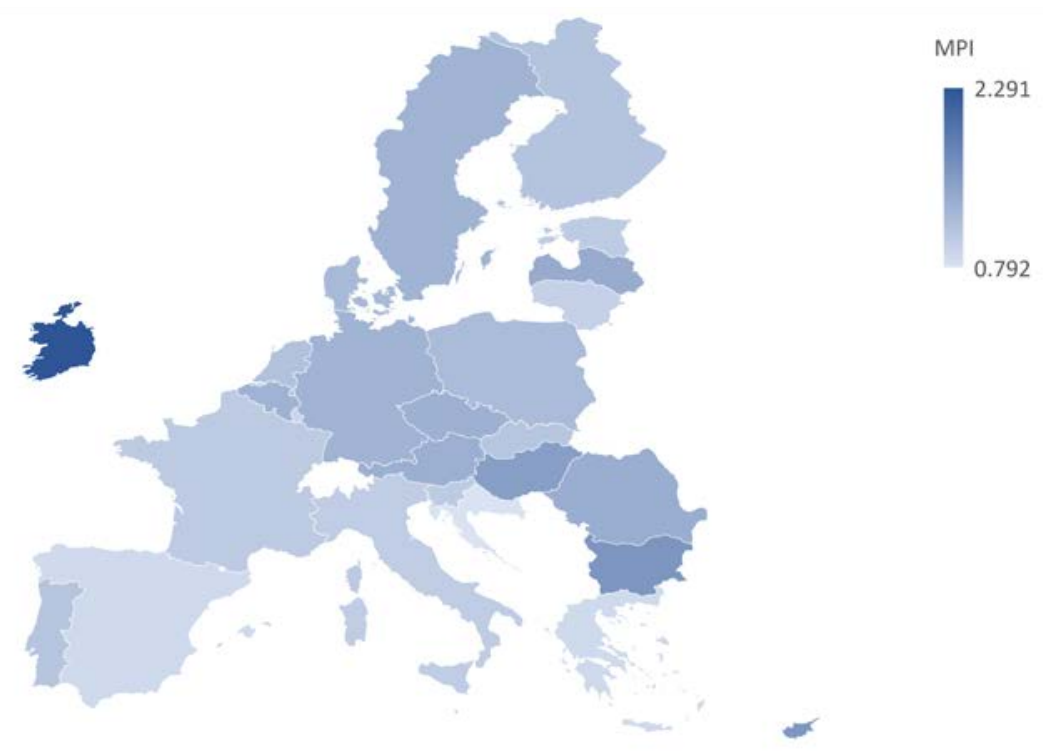

Graph 2 Regional comparison of changes in productivity between years 2010 and 2018 
As we can observe, productivity growth was recorded mainly in countries that were severely affected by the crisis - the Baltic countries, Ireland, Germany etc., as well as in the countries that joined the EU at that time - Bulgaria and Romania. This suggests in particular that growth was due to massive investment in the post-crisis period. On the contrary, the countries generating high GDP ratio from tourism - the Mediterranean countries - experienced either a decline or small increase in productivity.

The research findings show that investment into tourism infrastructure can result in overall improvement of the sector. One possible solution is green tourism. Investments aimed at improving the business environment and energy uses of buildings is the basis for recovery of the tourism industry. Future research could focus on measuring the impacts of the pandemic on the productivity of selected EU regions.

\section{References}

1. Androniceanu, A. (2020). Major structural changes in the EU policies due to the problems and risks caused by COVID-19. Administratie si Management Public, 34, 137-149. DOI: 10.24818/amp/2020.34-08.

2. Androniceanu, A., Marton, D.- M., (2021). The psychosocial impact of the Romanian government measures on the population during the COVID-19 pandemic. Central European Public Administration Review, 19(1), 7-32.

3. Bampatsou C, Halkos G and Astara O-H (2020) Composite indicators in evaluating tourism performance and seasonality. Operational Research: $24 . \quad$ DOI: https://doi.org/10.1007/s12351-020-00610-5.

4. Barros CP and Alves FP (2004) Productivity in the tourism industry. International Advances in Economic Research 10(3): 215-225. DOI: 10.1007/BF02296216.

5. Benito B, Solana J and López P (2014) Determinants of Spanish Regions' Tourism Performance: A Two-Stage, Double-Bootstrap Data Envelopment Analysis. Tourism Economics 20(5): 987-1012. DOI: 10.5367/te.2013.0327.

6. Bilan, Y., Mishchuk, H., and Pylypchuk, R. (2017). Towards sustainable economic development via social entrepreneurship. Journal of Security and Sustainability Issues, 6(4), 691-702. 
7. Chaabouni, S. (2019). China's regional tourism efficiency: A two-stage double bootstrap data envelopment analysis. Journal of Destination Marketing \& Management 11: 183-191. DOI: 10.1016/j.jdmm.2017.09.002.

8. Chenghu, Z., Arif, M., Shehzad, K., Ahmad, M., \& Oláh, J. (2021). Modeling the Dynamic Linkage between Tourism Development, Technological Innovation, Urbanization and Environmental Quality: Provincial Data Analysis of China. International Journal of Environmental Research and Public Health, 18(16): 8456, 1-21. DOI: 10.3390/ijerph18168456.

9. Cho T-Y and Wang T-Y (2018) Estimations of cost metafrontier Malmquist productivity index: using international tourism hotels in Taiwan as an example. Empirical Economics 55(4): 1661-1694. DOI: 10.1007/s00181-017-1329-z.

10. Corne A (2015) Benchmarking and tourism efficiency in France. Tourism Management 51: 91-95. DOI: 10.1016/j.tourman.2015.05.006.

11. Corne A and Peypoch N (2020) On the determinants of tourism performance. Annals of Tourism Research 85: 103057. DOI: 10.1016/j.annals.2020.103057.

12. Csikósová, A., Janošková, M., Čulková, K. (2020). Providing of tourism organizations sustainability through Tripple Bottom Line approach. Entrepreneurship and Sustainability Issues 8(2), 764-776. DOI: 10.9770/jesi.2020.8.2(46).

13. Dobrovič, J., Rajnoha, R., Korauš, A. (2018) Effectiveness and performance of tax system in Slovak Republic in terms of its key non-macroeconomics factors. Oeconomia Copernicana, 9 (4), pp. 617-634. DOI: 10.24136/oc.2018.030.

14. Duro JA, Perez-Laborda A, Turrion-Prats J, et al. (2021) Covid-19 and tourism vulnerability. Tourism Management Perspectives 38: 100819. DOI: 10.1016/j.tmp.2021.100819.

15. Eurostat (2021) Database - Eurostat. Available at: https://ec.europa.eu/eurostat/data/database (accessed 30 January 2020).

16. Färe R, Grosskopf S, Lindgren B, et al. (1994) Productivity Developments in Swedish Hospitals: A Malmquist Output Index Approach. In: Data Envelopment Analysis: Theory, Methodology, and Applications. Dordrecht: Springer Netherlands, pp. 253-272. DOI: 10.1007/978-94-011-0637-5_13. 
17. Halasi, D., Schwarcz, P., Mura, L., Roháčiková, O. (2019). The impact of EU support resources on business success of family-owned businesses. Potravinarstvo Slovak Journal of Food Sciences, 13 (1), pp. 846-853. ISSN 1337-0960. https://doi.org/10.5219/1167.

18. Havierniková, K., Lemańska-Majdzik, A., Mura, L. (2017). Advantages and Disadvantages of the Participation of SMEs in Tourism Clusters. Journal of Environmental Management and Tourism, Vol. 8., No. 6, pp. 1205- 1215. ISSN 2068 - 7729.

19. Huang C (2018) Assessing the performance of tourism supply chains by using the hybrid network data envelopment analysis model. Tourism Management 65: 303-316. DOI: 10.1016/j.tourman.2017.10.013.

20. Ilić I Petrevska I (2018) Using DEA method for determining tourism efficiency of Serbia and the surrounding countries. Menadzment u hotelijerstvu i turizmu 6(1): 73-80. DOI: 10.5937/menhottur1801073I.

21. Kinnunen, J., Georgescu, I., Hosseini, Z., \& Androniceanu, A.-M. (2021). Dynamic indexing and clustering of government strategies to mitigate Covid-19. Entrepreneurial Business and Economics Review, 9(2), 7-20. https://doi.org/10.15678/EBER.2021.090201.

22. Korauš, A., Dobrovič, J., Rajnoha, R., Brezina, I. (2017a). The safety risks related to bank cards and cyber-attacks, Journal of Security and Sustainability Issues 6(4): 563-574. https://doi.org/10.9770/jssi.2017.6.4(3).

23. Korauš, A., Kaščáková, Z., Parová, V., Veselovská, S. (2017b). Sustainable economic development through human resource management: social intelligence of managers and performance. Journal of Security and Sustainability Issues 6(3): 457-477. https://doi.org/10.9770/jssi.2017.6.3(11).

24. Korshenkov, E., Ignatyev, S. 2020. Empirical interpretation and measurement of the productivity and efficiency of regions: The case of Latvia. Insights into Regional Development, 2(2), 549-561. DOI: 10.9770/IRD.2020.2.2(4).

25. Marčeková, R., Šebová, L., Pompurová, K., Šimočková, I. (2021). Accessible tourism current state in Slovakia. Entrepreneurship and Sustainability Issues, 9 (1), 66-86. DOI: 10.9770/jesi.2021.9.1(5). 
26. Mariš, M. 2019. Structural and productivity shift of industries in Slovakia and Czech Republic: A comparative study. Journal of International Studies,12 (1), 313-323. DOI: 10.14254/2071-8330.2019/12-1/21.

27. Maris, M., Kovacik, M., \& Fazikova, M. (2019). Commuting trends and patterns behind the regional imbalances in Slovakia. European Journal of Geography, 10 (1): 23-36.

28. Marišová, E., Lichnerová, I., Machyniak, J. (2021). Efficiency of the functioning of public administration: Regional empirical study. Administratie si Management Public, 36, 165180. DOI: 10.24818/AMP/2021.36-10.

29. Martin JC, Mendoza C and Román C (2017) A DEA Travel-Tourism Competitiveness Index. Social Indicators Research 130(3): 937-957. DOI: 10.1007/s11205-015-1211-3.

30. Mavi NK and Mavi RK (2019) Energy and environmental efficiency of OECD countries in the context of the circular economy: Common weight analysis for malmquist productivity index. Journal of Environmental Management 247: 651-661. DOI: 10.1016/j.jenvman.2019.06.069.

31. Mura, L. (2020). Marketing Management of Family Businesses: Results of Empirical Study. International Journal of Entrepreneurial Knowledge, 8(2), 56-66. doi: 10.37335/ijek.v8i2.118.

32. Mura, L., Kajzar, P. (2018). Entrepreneurship in Tourism Sector In Central European Country: Hospitality Trends in the Czech Republic in 2007 - 2016. Journal of Environmental Management and Tourism, Vol. 9., No. 6 (30), pp. 1351 - 1360. ISSN 2068 - 7729 . doi:10.14505//jemt.v9.6(30).25.

33. Niavis S and Tsiotas D (2019) Assessing the tourism performance of the Mediterranean coastal destinations: A combined efficiency and effectiveness approach. Journal of Destination Marketing \& Management 14: 100379. DOI: 10.1016/j.jdmm.2019.100379.

34. Oláh, J., Kitukutha, N., Haddad, H., Pakurár, M., Máté, D., \& Popp, J. (2019). Achieving sustainable e-commerce in environmental, social and economic dimensions by taking possible trade-offs. Sustainability, 11(1): 89. 1-22. DOI: 10.3390/su11010089.

35. Piątkowski, M. J. (2020). Implementation of innovations in enterprises using the EU funds:A comparative analysis. Journal of International Studies, 13(2), 109-126. doi:10.14254/2071-8330.2020/13-2/8. 
36. Peypoch N and Solonandrasana B (2008) Aggregate Efficiency and Productivity Analysis in the Tourism Industry. Tourism Economics 14(1): 45-56. DOI: 10.5367/000000008783554794.

37. Prokopenko, O. et al. (2020). Adaptation of the development of ecological entrepreneurship. International Journal of Scientific and Technology Research, 9(3), pp. 1112-1115.

38. Prokopenko, O., Omelyanenko, V. (2020). Intellectualization of the Phased Assessment and Use of the Potential for Internationalizing the Activity of Clusters of Cultural and Creative Industries of the Baltic Sea Regions. TEM Journal, 9 (3), pp. 1068-1075. DOI: 10.18421/TEM93-31.

39. Radjenovic, M., Draskovic, M., Pupavac, J. (2020). Analysis of The Southeastern European Countries' Cultural and Creative Tourism Competitiveness. Transformations in Business \& Economics, 19, 2 (50), pp.259-270.

40. Rudminas, L., \& Baležentis, T. (2020). (Non-)Convex production metafrontier for the Baltic states. Economics and Sociology, 13(2), 228-244. doi:10.14254/2071789X.2020/13-2/15.

41. Qiu X, Fang Y, Yang X, et al. (2017) Tourism Eco-Efficiency Measurement, Characteristics, and Its Influence Factors in China. Sustainability 9(9), 1634. DOI: 10.3390/su9091634.

42. Skare, M., Kukurin, Z. (2020). Measuring the Effects of VAT Changes on the Tourism Industry: the Case of Croatia. Transformations in Business \& Economics, 19, 2 (50), pp.271-282.

43. Soysal-Kurt H (2017) Measuring Tourism Efficiency of European Countries by Using Data Envelopment Analysis. European Scientific Journal, ESJ 13(10): 31. DOI: 10.19044/esj.2017.v13n10p31.

44. Sun J, Zhang Jie, Zhang Jinhe, et al. (2015) Total Factor Productivity Assessment of Tourism Industry: Evidence from China. Asia Pacific Journal of Tourism Research 20(3): 280-294. DOI: 10.1080/10941665.2013.877047.

45. The World Bank (2021) World Bank Open Data. Available at: https://data.worldbank.org/ (accessed 10 February 2021). 
46. Valenćiková M, Marišová E (2021) Efficient waste management solutions provider for cities and businesses with focus on Nitra city: Sensoneo start-up. Innovative businesses and start-ups in current business environment: Bratislava: Pan-European University, 3839.

47. Zhang H, Song H, Wen L, et al. (2021) Forecasting tourism recovery amid COVID-19. Annals of Tourism Research 87: 103149. DOI: 10.1016/j.annals.2021.103149.

48. Żak, M., \& Garncarz, J. (2020). Economic policy towards the challenges of the COVID19 pandemic in selected European Union countries. International Entrepreneurship Review, 6(4), 21-34. https://doi.org/10.15678/IER.2020.0604.02.

49. Zopiatis A, Pericleous K and Theofanous Y (2021) COVID-19 and hospitality and tourism research: An integrative review. Journal of Hospitality and Tourism Management 48: 275279. DOI: 10.1016/j.jhtm.2021.07.002. 